Pintner, I. J. \& Provasoli, L. (1958). J. gen. Microbiol. 18, 190-197

\title{
Artificial Cultivation of a Red-Pigmented Marine Blue-Green Alga, Phormidium persicinum
}

\author{
By IRMA J. PINTNER AND L. PROVASOLI \\ Haskins Laboratories, New York, N.Y., U.S.A.
}

\begin{abstract}
SUMMARY: Phormidium persicinum requires light intensities $<300$ foot-candles and grows at $10^{\circ}-33^{\circ}$. The medium developed for $P$. persicinum is representative of the early types of artificial media having a relatively high concentration of chelator and, necessarily, of trace metals. Other media, varying widely in trace metal: chelator ratios and concentrations allow growth of $\boldsymbol{P}$. persicinum. Tris 2-amino-2hydroxymethylpropane-1:3-diol is a suitable $\mathrm{pH}$ buffer; its antagonism of potassium utilization was demonstrated and was amply overcome by the addition of $200 \mathrm{mg}$. $\mathrm{K} / \mathrm{l}$. to the medium. Inorganic and organic phosphates were utilized and were required at relatively low concentrations. $P$. persicinum utilized $\mathrm{NO}_{3}^{-}$and $\mathrm{NH}_{4}^{+}$but not atmospheric nitrogen. $\mathrm{NaNO}_{3}$ was the most satisfactory inorganic nitrogen source but the cultures bleached after prolonged growth. Asparagine $(0 \cdot 2-0 \cdot 8 \mathrm{~g} . / 1$.$) maintained the normal purple pigmentation over a longer period; it$ served as a non-toxic slowly-utilized reservoir of available $\mathbf{N}$. Vitamin $\mathbf{B}_{12}$ is the only essential vitamin and is needed at a concentration $(100 \mathrm{~m} \mu \mathrm{g} . / 1$.$) which is higher than$ for most algae. All the cobalamins including factor $B$, but not methionine or deoxyribosides, can substitute for vitamin $\mathbf{B}_{12}$. The physiological and ecological resemblances of $\boldsymbol{P}$. persicinum to red or violet blue-green algae growing in deep water are discussed.
\end{abstract}

The nutrition and other aspects of the physiology of the blue-green pigmented members of the Cyanophyceae have been much studied but little has been done with the red-pigmented species, which, according to ecological observations, colonize and prefer deeper water layers.

Phormidium persicinum was isolated from a bottle of Wood's Hole sea water which had been stored in dim fluorescent light for 6-8 months. The growth appeared as small purple tufts at the bottom and on the walls of the bottle. Fragments were placed on the centre of agar plates of Föyn's 'Erdschreiber' sea water (Föyn, 1934) to which had been added 1000 units penicillin/ml. and $25 \mu \mathrm{g}$. dihydrostreptomycin $/ \mathrm{ml}$. $P$. persicinum in liquid media withstands $20 \mu \mathrm{g}$. dihydrostreptomycin $/ \mathrm{ml}$. for a month with no bleaching; other bluegreen algae appear to be much more sensitive to streptomycin. Heavy bacterial growth was suppressed by the antibiotics and the filaments grew rapidly outward, leaving most bacteria behind. Two transfers of filaments from the outer zone were necessary to establish a bacteria-free culture (by cutting a block of agar with filaments from the outer zone and inverting on a new plate without antibiotics). Cultures were at first maintained on Föyn's 'Erdschreiber' agar slopes, and later in medium ASW III (Table 1).

In all but the earliest experiments, an all-glass technique described by Hutner, Provasoli \& Filfus (1953) was used. Experimental cultures were grown in $10 \mathrm{ml}$. of liquid media in $25 \mathrm{ml}$. Erlenmeyer flasks with glass caps. 
To prepare uniform inocula from the thick filamentous mat, cultures were grown with sterile glass beads and shaken at intervals as suggested by Fogg (1942); the alga then grows in more or less separate filaments. In later experiments, to

Table 1. Sea-roater medium for maintenance of Phormidium persicinum

\begin{tabular}{|c|c|c|c|}
\hline \multicolumn{4}{|c|}{ Medium ASW III } \\
\hline $\begin{array}{l}\text { Sea water } \\
\mathrm{KNO}_{3} \\
\mathrm{~K}_{2} \mathrm{HPO}_{4} \\
\mathrm{Fe} \text { (as chloride) } \\
\text { Soil extract } \\
\text { Mn (as chloride) }\end{array}$ & $\begin{array}{l}100 \mathrm{ml} . \\
0.02 \mathrm{~g} . \\
0.002 \mathrm{~g} . \\
0.01 \mathrm{mg} . \\
4 \mathrm{ml} . \\
0.04 \mathrm{mg} .\end{array}$ & $\begin{array}{l}\text { NaH glutamate } \\
\text { Glycine } \\
\text { ' } 1: 20 \text { liver'* } \\
\text { Vitamin Mixture } 8 \dagger \\
\text { pH } 7 \cdot 5\end{array}$ & $\begin{array}{l}0.05 \mathrm{~g} . \\
0.05 \mathrm{~g} . \\
0.001 \mathrm{~g} . \\
0.1 \mathrm{ml} .\end{array}$ \\
\hline
\end{tabular}

obtain comparative values of growth within each experiment and from one experiment to another, cultures were ground for 5-10 min. in a 'Virtis' microhomogenizer and the optical density measured with a Densichron (W. M. Welch Sci. Co., Chicago).

\section{RESULTS}

Physical factors which affect growth of Phormidium persicinum

We soon saw that illumination good for other photosynthetic organisms did not suit Phormidium persicinum. Light intensities $>\mathbf{3 0 0} \mathrm{ft}$.c. hampered pigment formation and growth; the optimal intensities lay between 100 and $200 \mathrm{ft}$.c. of white fluorescent light. $\boldsymbol{P}$. persicinum grows at temperatures up to $33^{\circ}$; experiments were normally carried out at $20^{\circ}-25^{\circ}$ and the stock cultures were kept at $10^{\circ}-15^{\circ}$ in dim light. In stationary liquid cultures, $P$. persicinum tended to form a thick mat on the surface; there was usually also some submerged growth, especially in test tubes. In one experiment, aeration for 17 days did not speed growth or increase the yield.

\section{Mineral nutrition}

The first chemically-defined medium to support good growth contained organic constituents (amino acids, purines and pyrimidines) later found inessential. The present medium (Table 2) clarified several points concerning the construction of chemically-defined media for marine organisms (Provasoli, McLaughlin \& Droop, 1957). Ca and $\mathrm{Mg}$ concentrations are widely interchangeable, as with many other marine organisms (Provasoli, McLaughlin \& Pintner, 1954). With a concentration of $\mathrm{Mg}$ corresponding to that in sea water (1.2 g./l.), the Ca concentration can be decreased to $10 \mathrm{mg}$./1. (1/40 sea-water concentration); $\mathrm{Mg}$ above sea-water concentration inhibits. With $\mathrm{Ca}$ at $300 \mathrm{mg}$./l. (3/4 sea water), $\mathrm{Mg}$ can be decreased to 50-100 mg./l. Calcium at $80 \mathrm{mg}$./l. and $\mathrm{Mg}$ at 600-700 mg./l. are optimal in a medium containing $200 \mathrm{mg}$. ethylenediaminetetraacetic acid (EDTA)/l. at pH 7·0-7.2. Similar $\mathrm{Ca}+\mathrm{Mg}$ combinations can be employed with different concentrations of trace-metal+ chelator mixtures. 
Concentrations of $\mathrm{NaCl}>3 \%$ or $<1.5 \%(w / v)$ decrease growth. $\mathrm{NaCl}$ cannot be substituted osmotically, even partly, by pentaerythritol which seems toxic at concentrations as low as $0.5 \mathrm{~g} . / \mathrm{l}$.

Potassium is needed in low concentration $(5 \cdot 0 \mathrm{mg}$./1.). Since most media become alkaline during growth, buffering to maintain a constant $\mathrm{pH}$ value is important in order to prevent a damaging shift in metal balance. Of the buffers tried, tris was the most satisfactory. However tris (buffer) antagonized $\mathbf{K}$ utilization by bacteria (MacLeod \& Onofrey, 1954). This also holds for Phormidium persicinum: with $1 \mathrm{~g}$. tris (buffer)/l., which buffers adequately, the requirement for $\mathrm{K}$ was raised to $40-50 \mathrm{mg}$./l. Our present media have ample $\mathrm{K}(400 \mathrm{mg} . \mathrm{KCl} / \mathrm{l}=\mathbf{2 0 0} \mathrm{mg}$. $\mathrm{K} / \mathrm{l}$.) thus avoiding antagonism by tris (buffer). With suitable adjustment of the trace metals, $\boldsymbol{P}$. persicinum can be grown between $\mathrm{pH} 6 \cdot 0$ and $\mathrm{pH} 8 \cdot 0$.

\section{Table 2. Defined medium for Phormidium persicinum}

$\begin{array}{llll}\text { EDTA } & 20 \mathrm{mg} . & \mathrm{MgSO}_{4} .7 \mathrm{H}_{2} \mathrm{O} & 0.5 \mathrm{~g} . \\ \mathrm{NaCl} & 2.5 \mathrm{~g} . & \mathrm{NaNO}_{3} & 10 \mathrm{mg} . \\ \mathrm{Metal} \mathrm{mix} & 0.4 \mathrm{ml} . & \text { DL-Asparagine }^{*} & 20 \mathrm{mg} \text {. } \\ \mathrm{Fe} \text { (as chloride) } & 0.4 \mathrm{mg} . & \mathrm{K}_{3} \mathrm{PO}_{4} & 5 \mathrm{mg} . \\ \mathrm{KCl} & 40 \mathrm{mg} . & \text { Vitamin }_{12} & 0.2 \mu \mathrm{g} . \\ \mathrm{Ca} \text { (as chloride) } & 8 \mathrm{mg} . & \text { Tris } & 100 \mathrm{mg} .\end{array}$

Distilled water to $100 \mathrm{ml} . \mathrm{pH}$ adjusted to $7 \cdot 0$

* Metal mix. $100 \mathrm{ml}$. of the mixture contains the following concentrations of the metals (mg.; calculated as chlorides): $\mathrm{Mn} 4 ; \mathrm{Zn} 4 ; \mathrm{Cu} 0.1 ; \mathrm{Co} 0.05 ; \mathrm{Fe} 0.2$; citric acid. $\mathrm{H}_{2} \mathrm{O} 3$.

Phormidium persicinum can utilize inorganic and organic phosphates; $0.3 \mathrm{mg} . \mathrm{K}_{3} \mathrm{PO}_{4} /$ l. is the minimal concentration for appreciable growth and it is tolerated up to at least $300 \mathrm{mg} . / 1 . ; \mathrm{K}$ glycerophosphate is utilized from 0.3 to $10 \mathrm{mg} . / 1 . ; 100 \mathrm{mg}$./l. is toxic. Guanylic, cytidylic, and yeast adenylic acids are also utilizable as phosphorus sources from 1 to $100 \mathrm{mg}$./l., with optimal growth at $10 \mathrm{mg} . / \mathrm{l}$. These values are much lower than those required by $\boldsymbol{P}$. autumnale, a fresh-water species now being studied.

Atmospheric nitrogen is not utilized by Phormidium persicinum. Fogg \& Wolfe (1954) reported that many blue-green algae fix nitrogen, others not. They suggested that this inability may result from lack of molybdenum. The addition of $\mathbf{0 . 2} \mathrm{mg}$. Mo/l. to the $\boldsymbol{P}$. persicinum medium did not permit utilization of $\mathbf{N}_{\mathbf{2}}$ nor was growth with nitrate or ammonia enhanced. Molybdenum is apparently amply supplied as an impurity in the reagent-quality salts of the medium. Both $\mathrm{NO}_{3}^{-}$and $\mathrm{NH}_{4}^{+}$are good $\mathrm{N}$ sources and, as Kinne-Diettrich (1955) reported for two marine species (Lyngbya confervoides, L. maiscula), $\mathrm{NO}_{3}^{-}$is better than $\mathrm{NH}_{\mathbf{4}}^{+}$. Glycine is poor, and lysine, histidine, glutamic acid and aspartic acid are inert as $\mathbf{N}$ sources. Asparagine is utilized, and nitrate + asparagine gives better growth than either alone. Biotin (up to $1 \mathrm{mg}$./l.) does not increase asparagine utilization.

No carbon sources tested affected total growth (i.e. they seemed not to be utilized) and they did not permit growth in darkness, yet they seemed to 
influence the permanence of the normal purple colour.* Acetate, glycerol, mannitol, succinate, fumarate and ethanol as single added $\mathrm{C}$ sources gave orange-yellow to dirty yellow-brown cultures; glycine, alanine and asparagine maintained normal pigmentation. Cultures with $\mathrm{NO}_{3}^{-}\left(100-200 \mathrm{mg}\right.$. $\mathrm{NaNO}_{3} / 1$.) as the sole $\mathbf{N}$ source turned pink, then yellowish and finally bleached after a month or so. With asparagine $200-800 \mathrm{mg}$./l. added to the $\mathrm{NO}_{3}^{-}$medium, the purple coloration persisted for at least 3 months; glycine and alanine acted in the same way but the cultures faded earlier; this did not depend on the utilization as a carbon source of the deaminated molecule, for aspartic acid added to the medium containing $\mathrm{NO}_{3}^{-}$or $\mathrm{NH}_{4}^{+}$neither increased growth nor favoured persistence of pigmentation.

The medium developed for Phormidium persicinum represents one of the earlier types of artificial marine media which contained a relatively high concentration (200 mg./l.), of ethylenediaminetetraacetic acid (EDTA) and a correspondingly higher content of trace metals. This ratio is important, as is total concentration of minor elements necessary to compensate for the binding action of EDTA. A single heavy metal, e.g. Fe or Zn, is tolerated in higher concentration when the other trace elements are at a higher concentration also. This might explain why mixtures of chelator and trace metals like that embodied in the medium $\mathrm{ASP}_{7}$ of Table 3 are non-toxic in a wide range of

Table 3. Marine medium $\mathrm{ASP}_{2}$; (Provasoli, unpublished)

\begin{tabular}{|c|c|c|c|}
\hline $\begin{array}{l}\mathrm{NaCl} \\
\mathrm{MgSO}_{4} \cdot 7 \mathrm{H}_{2} \mathrm{O}\end{array}$ & $\begin{array}{l}2.5 \mathrm{~g} . \\
0.9 \mathrm{~g} .\end{array}$ & $\begin{array}{l}\text { PI metal mixture* } \\
\text { NTA (nitrilotriacetic } \\
\text { acid) }\end{array}$ & $\begin{array}{l}3 \mathrm{ml} . \\
7 \mathrm{mg} .\end{array}$ \\
\hline $\mathrm{Ca}$ (as chloride) & $30 \mathrm{mg}$. & Tris & $0 \cdot 1 \mathrm{~g}$. \\
\hline $\mathrm{KCl}$ & $0.07 \mathrm{~g}$. & Vitamin $\mathbf{B}_{12}$ & $0 \cdot 1 \mu \mathrm{g}$. \\
\hline $\mathrm{NaNO}_{3}$ & $5 \mathrm{mg}$. & Vitamin mixture $\dagger$ & $1 \mathrm{ml}$. \\
\hline $\mathbf{K}_{\mathbf{2}}$ glycerophosphate & $2 \mathrm{mg}$. & $\mathrm{H}_{2} \mathrm{O}$ to & $100 \mathrm{ml}$ \\
\hline $\mathrm{Na}_{2} \mathrm{SiO}_{3} \cdot 9 \mathrm{H}_{2} \mathrm{O}$ & $7 \mathrm{mg}$. & $\mathrm{pH} 7 \cdot \mathbf{8 - 8} \cdot \mathbf{0}$ & \\
\hline
\end{tabular}

* PI metal mixture. $1 \mathrm{ml}$. contains (mg.): $\mathrm{Na}_{2}$ EDTA 1 ; Fe (as chloride) 0.01 ; Boron (as $\mathrm{H}_{3} \mathrm{BO}_{3}$ ) 0.2; $\mathrm{Mn}$ (as chloride) 0.04; $\mathrm{Zn}$ (as chloride) 0.005; $\mathrm{Cu}$ (as chloride) 0.00004; Co (as chloride) $0 \cdot 0001$.

$\dagger$ See Table 1. Not essential for Phormidium persicinum.

concentrations. Total salinity and the $\mathrm{Ca}: \mathrm{Mg}$ and trace metal: chelator ratios and concentrations can differ quite widely as indicated by the ability of $\boldsymbol{P}$. persicinum to grow in diverse artificial media. In the earlier, presumably unbalanced, media the addition of guanine or other purines and pyrimidines was stimulatory. This effect was also observed during the development of good basal media for other fresh-water and marine organisms, and can be ascribed to interactions and impurities.

\section{Growth factors}

The mineral requirements of Phormidium persicinum were studied in media containing a mixture of the $\mathbf{B}$ vitamins (Cowperthwaite, Weber, Packer \&

* The colour values given in the text are followed by the corresponding standard colour descriptions of Ridgway (1912) : purple = between $71 \mathrm{~K}$ (Bordeaux) and $69 \mathrm{~K}$ (Pansy Purple); pink $=1 \mathrm{f}$ (Venetian Pink); orange-yellow $=15 \mathrm{~b}$ (Ochraceous Buff); dirty yellow-brown = $17 \mathrm{~K}$ (Dresden Brown); yellowish $=21 \mathrm{~b}$ (Amber Yellow); red-brown $=7 \mathrm{~m}$ (Liver Brown). 
Hutner, 1953). During the dissection of this mixture to find the vitamins responsible for growth, thiamine seemed needed (Provasoli \& Pintner, 1954). This effect disappeared following complete depletion of the organisms by serial transfers of washed inoculum; only vitamin $B_{12}$ was then required. The need for cyanocobalamin was high in comparison with that of other algae, namely $0.1 \mu \mathrm{g}$./1. for full growth. All the other cobalamins, even factor $\mathbf{B}$ (the nonnucleotide moiety of the cobalamins) substituted for intact vitamin $B_{12}$ (Table 4). This lack of specificity is similar to that for Escherichia coli 113-3,

Table 4. Growth response of Phormidium persicinum to cobalamins

The relative amounts of growth are expressed in optical density values.

\begin{tabular}{|c|c|c|}
\hline \multicolumn{3}{|c|}{$\begin{array}{l}\text { Concentration of factor added } \\
\qquad(\mathrm{m} \mu \mathrm{g} \cdot / \mathrm{l} .)\end{array}$} \\
\hline 10 & 100 & 1000 \\
\hline \multicolumn{3}{|c|}{ optical density values } \\
\hline $0 \cdot 24$ & 0.50 & 0.74 \\
\hline $0 \cdot 36$ & $0 \cdot 49$ & 0.62 \\
\hline 0.31 & 0.48 & 0.51 \\
\hline $0 \cdot 23$ & 0.43 & $0 \cdot 64$ \\
\hline $0 \cdot 36$ & $0 \cdot 43$ & 0.49 \\
\hline $0 \cdot 32$ & $0 \cdot 46$ & 0.63 \\
\hline 0.43 & 0.44 & 0.47 \\
\hline $0 \cdot 40$ & $0 \cdot 41$ & 0.47 \\
\hline 0.04 & 0.04 & 0.04 \\
\hline
\end{tabular}

Amphora perpusilla (McLaughlin \& Provasoli, unpublished), and Skeletonema costatum (Droop, 1955). Phormidium persicinum seems unable to replace vitamin $\mathbf{B}_{12}$ with methionine (as can Escherichia coli) or with deoxyribonucleotides (as can Lactobacillus leichmannii and $\boldsymbol{L}$. lactis). This broad specificity may constitute a significant ecological advantage (Provasoli, 1957).

\section{DISCUSSION}

Wille (1922) found that Phormidium persicinum is abundant at depths of $20 \mathrm{~m}$. on the south coast of Norway. Many records show that the blue-green algae inhabiting deep waters are red or violet; numerous red algae also thrive in the same locale. The ability of these algae to grow in deep waters is due to their accessory pigments ( $c$ - or $r$-phycoerythrin) which enables them to utilize bluegreen light, the light which penetrates deeper into the waters. None the less such ability should not prevent them from growing in shallower waters where the entire spectrum is offered them, and other factors, such as light intensity (low in deep waters) should become significant for the species which are consistently found only in deeper waters. Indeed, $P$. persicinum is hampered by light intensities above $300 \mathrm{ft} . c$. and prefers intensities between 100 and $200 \mathrm{ft}$.c. Since the cultures were grown under fluorescent lights (rich in blue-green light) our conditions may resemble the natural habitat of the species. $P$. persicinum appears, then, to be a true shade form admirably fit to colonize its ecological 
niche. Fritsch has already postulated that the blue-green algae may be divided into light- and shade-loving species (Fritsch, 1945, p. 785).

Other red-pigmented blue-green algae may have similar light requirements: Feldman (1932) collected from draggings at Banyuls (Pyrénées Orientales, France) several species of red-pigmented Cyanophyceae, which were living epiphytically at a depth of $30 \mathrm{~m}$., among them Trichodesmium erythraeum. $T$. erythraeum had been considered a pelagic species because of its periodic surface blooms which are responsible for the naming of the Red Sea and the Vermillion Sea (Gulf of California). Feldman postulated that $\boldsymbol{T}$. erythraeum may actually grow far down and, under certain conditions, become detached, abandon its usual habitat and float at the surface; our observations on the light requirements of Phormidium persicinum, which, like Trichodesmium erythraeum, is an Oscillatoriacea, support Feldman's conclusions.

Some red-pigmented blue-green algae and red algae change colour (socalled colour adaptation) under different light conditions. Light of different wavelengths induces different pigmentation from red to orange, green and bluegreen (Boresch, 1921; Dangeard, 1911); however, Kylin (1937) and Harder (1922) have shown that light intensity (which was not controlled in Boresch's experiments) also influences the type of pigmentation. Even so Kylin supports the view of Boresch that colour adaptation is only possible in species possessing both phycocyanin and phycoerythrin and results from variations in the ratio of these two pigments; Boresch had not found any relation between quantity of chlorophyll and wavelength of incident-light. Improved chromatographic techniques offer the opportunity to resume the study of selective production of phycobilins in blue-green algae.

Colour changes are also induced by nutritional deficiencies or toxicities. Such changes have been observed in Phormidium persicinum and may be specific because they were observed under uniform light conditions and because this species has only $c$-phycoerythrin and no phycocyanin (Haxo, O'hEocha \& Norris, 1955). The obvious differences in pigmentation induced us to record the colour of the mats of filaments; the purple colour was taken as normal because this is the usual colour in nature and because it generally accompanies maximum growth. Whenever concentrations of nutrients or light conditions were unfavourable for growth, the red brownish colour prevailed, followed by the appearance of green patches, yellow-beige discoloration and, finally, bleaching. The pigment sometimes leached into the medium after two months: this happened more often in media containing $\mathrm{NH}_{4}^{+}$than with $\mathrm{NO}_{3}^{-}$; the $\mathrm{pH}$ value remained constant. Most brackish or marine organisms are sensitive to $\mathrm{NH}_{\mathbf{4}}^{+}$in the alkaline range (Provasoli et al. 1957) and the chrysomonad Prymnesium parvum actually lyses (Shilo \& Shilo, 1953). It may be that the loss of pigment reflects a change in permeability in old cultures of $\boldsymbol{P}$. persicinum, even though $\mathrm{NH}_{4}^{+}$does not hamper growth up to $0.5 \mathrm{~g}$. $\mathrm{NH}_{4} \mathrm{Cl} / \mathrm{l}$.

As noted, colour changes were most conspicuous with certain carbon sources. Asparagine, and to a lesser degree glycine, promoted a brilliant purple colour and prevented bleaching of old cultures; the higher the concentration of asparagine, the greater the duration and intensity of coloration. This effect 
might be due to several causes, among them impurities in the asparagine but, different samples, one of them synthetic (California Foundation for Biochemical Research), gave similar results. The $\mathrm{pH}$ value of the cultures with or without asparagine remained at $\mathrm{pH} 7 \cdot 7$ throughout the period of growth; this observation appears to eliminate a gross change in availability of trace metals as being responsible. Addition of a mixture of $\mathrm{Sr}, \mathrm{Li}, \mathrm{I}, \mathrm{Br}, \mathrm{B}, \mathrm{Rb}$, of various mixtures of trace metals, or of single heavy-metal salts, to low concentrations of asparagine $(200 \mathrm{mg}$./ $\mathrm{l}$.) did not elicit the lasting pigmentation obtained with higher concentrations of asparagine (600-800 mg./l.). Furthermore, Phormidium persicinum grew in many chemically-defined media developed for other marine protists (Provasoli et al. 1957) and in medium $\mathrm{ASP}_{7}$ (Table 3). At least several serial transfers could be made in these media which differed widely in respect to the content of chelator and trace metals, and to the chelator : trace metal ratio, which lessened the possibility of a deficiency in trace metals influencing pigmentation. Here again addition of asparagine resulted in prolonged pigmentation, suggesting that asparagine functioned primarily as an $\mathrm{N}$ source. Completely bleached old cultures grown with $\mathrm{NaNO}_{3}$ regained their purple colour in a few days after more $\mathrm{NaNO}_{3}$ was added. The effect of $\mathrm{N}$ deficiency on the coloration of several Rhodophyceae was described by Haxo \& Strout (1950) who observed uniform reddening within $24 \mathrm{hr}$. after addition of $\mathrm{KNO}_{3}$. Since increased concentrations of $\mathrm{NaNO}_{3}$ used alone (up to $1 \mathrm{~g}$./1.) increased the duration of pigmentation but did not equal that afforded by $100 \mathrm{mg}$. $\mathrm{NaNO}_{3}+600-800 \mathrm{mg}$. DL-asparagine/l., it seems likely that asparagine is utilized slowly and, being non-toxic even at high concentrations, provides a more lasting $\mathbf{N}$ reservoir and so permits growth during a longer period. It is possible that amino acids such as asparagine, alanine, etc., which favour pigmentation of $\boldsymbol{P}$. persicinum, supplement the scarce nitrates of warm seas and might even be important sources of $\mathbf{N}$ for algae growing in the depths, which implies that ability to utilize organic $\mathbf{N}$ is a significant ecological advantage. $\boldsymbol{P}$. persicinum was found by Wille growing on empty bryozoan shells attached to Laminaria saccharina - an environment presumably rich in products of bacterial metabolism. Trichodesmium erythraeum was found living also epiphytically at similar depths by Feldmann (1932), which suggests that these two species which share a common environment and may have similar light requirements may have common nutritional characteristics. These considerations increase the likelihood that $\boldsymbol{P}$. persicinum may serve as a guide in cultivating other ecologically important marine blue-green algae.

This work was supported in part by grant G-3216 of the National Institute of Health, U.S. Public Health Service and Contract NR-163-202 with the Office of Naval Research.

\section{REFERENCES}

Boresch, K. (1921). Die Komplementäre chromatische Adaptation. Arch. Protistenk. 44, 1.

Cowperthwaite, J., Weber, M. M., Packer, L. \& Hutner, S. H. (1953). Nutrition of Herpetomonas (Strigomonas) culcidarum. Ann. N.Y. Acad. Sci. 56, 972. 
Dangeard, P. A. (1911). Sur les conditions de l'assimilation chlorophylliene chez les Cyanophycées. C.R. Acad. Sci., Paris, 152, 967.

Droop, M. R. (1955). A pelagic marine diatom requiring cobalamin. J. mar. biol. Ass. U.K. 34, 229.

Feldmann, J. (1932). Sur la biologie des Trichodesmium Ehrenberg. Revue Algol. 6, 357.

FogG, G. E. (1942). Studies on nitrogen fixation by blue-green algae. I. Nitrogen fixation by Anabeana cylindria Lemm. J. exp. Biol. 19, 78.

FogG, G. E. \& Wolfe, M. (1954). The nitrogen metabolism of the blue-green algae. Symp. Soc. gen. Microbiol. 4, 99.

Föyn, B. (1934). Lebenszyklus, Cytologie und Sexualität der Chlorophycae Cladophora suhriana, Kutzing. Arch. Protistenk. 83, 1.

Fritsch, F. E. (1945). The Structure and Reproduction of the Algae, vol. I. Cambridge: University Press.

Harder, R. (1922). Lichtintensität und chromatische Adaptation bei den Cyanophyceen. Ber. dtsch. bot. Ges. 40, 26.

Haxo, F., O'HEocha, C. \& Norris, P. (1955). Comparative studies of chromatographically separated phycoerythrins and phycocyanins. Arch. Biochem. Biophys. 54, 162.

Haxo, F. \& Strout, P. (1950). Nitrogen deficiency and coloration in red algae. Biol. Bull., Wood's Hole, 99, 360.

Hutner, S. H., Provasoli, L. \& Filfus, J. (1953). Nutrition of some phagotrophic fresh-water Chrysomonads. Ann. N.Y. Acad. Sci. 56, 852.

KinNe-Dretrrich, E-M. (1955). Beiträge zur Kenntnis der Ernährungsphysiologie mariner Blaualgen. Kieler Meeresforsch. 11, 34.

Kylin, H. (1937). Über die Farbstoffe und die Furbe der Cyanophyceen. Forhand. K. Fysiogr. Sallsk. Lund, 7, no. 12.

MacLeod, R. A. \& Onofrey, E. (1954). Cation antagonism of the antibacterial action of amines. J. biol. Chem. 210, 193.

Provasoli, L. (1957). Growth factors in unicellular marine algae: Scripps Symposium on 'Perspectives in Marine Biology'. University of California Press. (In the Press.)

Provasoli, L., Mclaughlin, J. J. A. \& Droop, M. R. (1957). The development of artificial media for marine algae. Arch. Mikrobiol. 25, 392.

Provasoli, L., Mclaughlin, J. J. A. \& Pintner, I. J. (1954). Relative and limiting concentrations of major mineral constituents for the growth of algal flagellates. Trans. N.Y. Acad. Sci. 16, 412.

Provasoli, L. \& Pintner, I. J. (1954). Cultural characteristics of Phormidium persicinum, an auxotrophic marine red-pigmented blue-green alga. Rapports et Comm. du VIII Congres Inter. de Bot. Sect. 17, 39.

Ridgway, R. (1912). Color standards and Color Nomenclature. Washington, D.C.: Ridgway.

Shilo, M. \& ShIlo, M. (1953). Conditions which determine the efficiency of ammonium sulphate in the control of Prymnesium paroum in fish breeding ponds. Appl. Microbiol. 1, 330.

Wrlle, N. (1922). Phycoerythrin bei den Myxophyceen. Ber. dtsch. bot. Ges. 40, 188. 